\title{
Transatlantica
}

Revue d'études américaines. American Studies Journal

\section{The History of Miss Jane Pittman}

Ernest J. Gaines and the Slave Narrative

\section{Christopher Mulvey}

\section{CpenEdition}

Journals

Édition électronique

URL : http://journals.openedition.org/transatlantica/951

DOI : 10.4000/transatlantica.951

ISSN : $1765-2766$

Éditeur

AFEA

Référence électronique

Christopher Mulvey, "The History of Miss Jane Pittman », Transatlantica [En ligne], 1 | 2006, mis en ligne le 02 mai 2006, consulté le 29 avril 2021. URL : http://journals.openedition.org/transatlantica/ 951 ; DOI : https://doi.org/10.4000/transatlantica.951

Ce document a été généré automatiquement le 29 avril 2021.

\section{(c) (i)}

Transatlantica - Revue d'études américaines est mis à disposition selon les termes de la licence Creative Commons Attribution - Pas d'Utilisation Commerciale - Pas de Modification 4.0 International. 


\title{
The History of Miss Jane Pittman
}

\author{
Ernest J. Gaines and the Slave Narrative
}

\section{Christopher Mulvey}

1 This paper will explore the ways in which Ernest J. Gaines uses fiction in The Autobiography of Miss Jane Pittman to write a history of the African Americans from 1861 to 1961. The "Introduction" sets the novel going, but its direction has already been given in the unusual dedication to his grandmother, stepfather and aunt "who did not walk a day in her life but who taught me the importance of standing" (Gaines iv). The significance for Gaines is that what happened a hundred years ago is part of his present-day lived life. The nineteenth-century novel was possessed by history, and white nineteenth-century novelists found their great subject in the war of European nations that was fought between 1799 and 1815. But that was not an American war nor was it an African American war. For Gaines, the war that makes the great turning point of a nation and a people is the American Civil War, fought from 1861 to 1865. It resulted in a moment of history after which life would not be the same.

2 However, one of the main points that Gaines makes about that great turning point in history is that everything changed and nothing changed. And his main fictional device to establish that truth is to tell the history of the hundred years since Emancipation as the story of one woman. Her autobiography becomes an ethno-biography, and her story is one dedicated to all those about whom her story might be told, and the first names that we are given to whom this story relates are the names in the book's dedication. The Autobiography of Miss Jane Pittman is to be a relation about relations; however, I do not think that we need to detail the actual lives of Julia McVay, Ralph Norbert Colar and Augusteen Jefferson to begin a reading of The Autobiography of Miss Jane Pittman. Their lives make moving and instructive tellings, tellings that can be found in Mary Ellen Doyle's Voices from the Quarters: The Fiction of Ernest J. Gaines. But if we do not digress into history and if we begin to read Gaines's fiction, we see soon enough that the significance of the lives of these dead people is that the lives that they lived through the American Civil War and through the long years of Reconstruction and Deconstruction continued to be the lives lived by men and women born like Ernest J. 
Gaines in the 1930s and who, like Gaines, started their lives as field hands working for fifty cents a day before they were ten years old (Gaines 260).

3 Miss Pittman's story is a story of change without changes, and since in 2006 another forty years has elapsed since the times of her tellings, a question must now be raised: Have we seen more change without change? Are the descendants of Ernest J. Gaines as much caught in a trap of history as the descendants of the historical Julia McVay and of the fictional Jane Pittman? Towards the end of the novel, Miss Jane Pittman says, talking of Jimmy: "The first three or four years after he left here was the beginning of all that Civil Rights trouble. These white people had been living like this for hundreds and hundreds of years and they wasn't about to give up without a fight" (Gaines 230). The Civil War did away with Slavery and that was a great change, but Slavery was replaced by Segregation and that was no change. Between 1865 and 1900, the Slave Codes abolished by the 14th, 15th, and 16th Amendments to the United States Constitution were resurrected in the Jim Crow laws of the 1870s and 1880s (Johnson, T. 308, 430). In the New South, the African American was to be treated as a "perpetual alien" as George Washington Cable told the readers of The Century Magazine in January 1885: "They [that is, the white people of the South] spoke much of the negro's contentment with that servile condition for which nature had designed him. Yet there was no escaping the knowledge that we dared not trust the slave caste with any power that could be withheld from them. So the perpetual alien was made also a perpetual menial, and the belief became fixed that this, too, was nature's decree, not ours" (Cable).

4 Towards the end of the novel and towards the end of her life, Jane Pittman makes a long denunciation of the world of segregation: "You think a store would let you use a bathroom when they wouldn't even let you try clothes there? You gived them the number, they gived you the clothes. If they fit-good; if they didn't, that was too bad" (Gaines 244). Gaines's grandmother, Julia McVay, was a slave and she is the originating model for Miss Jane Pittman who is also his aunt, Augusteen Jefferson. By referencing Jane Pittman's life as the life of the black woman living between Civil War and Civil Rights, Gaines travels back one hundred years as though it were a yesterday, and in so doing so, he shows this woman and her compeers to be members of what Saul Bellow calls, in Herzog, "the senior dead" (Bellow 152), that is they are not members of what he calls in the same novel "the dead dead, without effect on the new generation" (Bellow 114). Miss Pittman living, breathing and talking in 1961, breaths the breath of her whole race, and she breathes for her race. That has fictive strength though it has ideological weakness. Miss Jane Pittman absorbs the identities of Julia McVay and Augusteen Jefferson, and of many other once identifiable and distinct human beings, and in creating his character Gaines not only honors these women, he obscures their memory.

5 In making an archetype, Gaines also makes a stereotype, but his creation gives him continuity forwards from 1861 through the life of the one woman whom he makes stand for all black women. And it was his aunt who taught him, he says, "the importance of standing" (Gaines iv). Gaines uses another device to provide a continuity backwards from 1861. The young man who wants to get Miss Jane Pittman's story upsets her with his persistence: “What you want know about Miss Jane for?' Mary said. 'I teach history,' I said. 'I'm sure her life's story can help me explain things to my students.' 'What's wrong with them books you already got?' Mary said. 'Miss Jane is not 
in them,' I said" (Gaines v). Ernest J. Gaines wrote at a time when historians finally began to recognize that they could get no true history of the South if they allowed that history to be written by plantation owners. In the sixties and the seventies, the preCivil War slave narratives, so long dismissed as lies and fictions by white Southern historians, began to be read again, and began to tell African Americans another history. Gaines used the then un-mined resources of the slave narratives to provide structure, themes, characters and incidents for his novel. A comparison of The Autobiography of Miss Jane Pittman with the Narrative of William W. Brown, A Fugitive Slave Written by Himself, published in 1847, will show how close these links are. But William Wells Brown's Narrative is only one of at least sixty pre-Civil War slave narratives, and, though it is an exceptionally good one, there is another reason for singling out its author.

William Wells Brown was the first African American to publish a novel: Clotel; or the president's daughter. That appeared in 1853, and up to that date Brown, like Equiano, Douglass, Bibb, Henson, Pennington, and the many others who wrote an account of their life as a slave and their escape from the South had had to contend with the Southern cry that everything the fugitive slaves were saying was lies, and that they did not write their own stories but got white Northerners to write them for them. It was the publication of Harriet Beecher Stowe's Uncle Tom's Cabin in 1852 which showed William Wells Brown (and Frederick Douglass) that fiction might serve the abolitionist cause as much as a true narrative faithfully attested. At the same time, for all that he had been a slave there, Brown seems to have loved the South more than he loved the North. He called his last work My Southern Home, and he was never at home in the North. To his dismay and disgust when he reached ohio and freedom in 1834, he found a physical hatred of blacks that he had not experienced in the slave states. He had run from Slavery to Segregation. And that is the story that Miss Jane Pittman has to tell of African Americans running from 1861 to 1961.

7 In 1853, with the publication of his novel Clotel, William Wells Brown took African American narrative in a direction that was new and dangerous. In 1971, with the publication of his novel Miss Jane Pittman, Ernest J. Gaines returned African American fiction to its roots, and he did so with a didactic purpose remarkably like that of William Wells Brown. It is the main purpose of this paper to talk about the links between The Autobiography of Miss Jane Pittman and the slave narrative, but it is worth mentioning certain links between Gaines's novel and the slave novel. One of the most suggestive is his inclusion of the tragic mulatta theme which so dominated the early slave novel. William Wells Brown's Clotel contains five such heroines, and the type appears in Frank J. Webb's The Garies and Their Friends of 1857, Hannah Crafts's The Bondwoman's Narrative of 1857, and Martin R. Delany's Blake; or the Huts of America of 1859. Of pre-Civil War African American novels, the only one in which the tragic mulatta does not figure is Harriet E. Wilson's Our Nig or, Sketches from the Life of a Free Black of 1859. That fact infuriated the 1960s critic-activist Addison Gayle. He blamed William Wells Brown for the false direction in which African American fiction had been set by Clotel. Brown, said Gayle, denied his people by surrendering "his racial identity to the American Mephistopheles for a pittance that Faust would have labeled demeaning" (Black Aesthetic 412).

8 Gayle published his attack on the first African American novelist in 1971, the year in which Gaines published The Autobiography of Miss Jane Pittman, and a major portion of 
that novel is given to telling the tragic story of a mulatta's love for a white man. Miss Mary Agnes LeFabre and Robert Tee Bob Samson work through the trope of the tragic mulatta. Gaines's telling is different from that of Brown's because Gaines makes it a tragedy of the white man not the white-skinned black woman. Tee Bob dies and Mary Agnes is sent away to New Orleans and the North (Gaines 184-209). But even though Gaines rings a remarkable variation on the old story, he nonetheless presents the figure of the richly named Mary Agnes LeFabre as a figure of deep melancholy and exquisite beauty exactly contrasting with the black black-women. Gaines is fatally drawn to the stereotype, and in 1971 he was drawn with less excuse than can be found for William Wells Brown in 1853.

But as much as The Autobiography of Miss Jane Pittman echoes the early slave novels, its deeper cultural source is the slave narrative. An incident in the opening pages of Book I, "The War Years," shows just how close Gaines's story is to the traditional slave narrative as the novel locates on that moment when the heroine first becomes, as it were, herself, her true self. She does so by taking on a new name, a name of her choosing and not one imposed by her owners. She does not respond when her mistress calls her, and she explains: "'You called me Ticey. My name aint Ticey no more. It's Miss Jane Brown." Miss Jane Brown is the name she has willingly taken from Corporal Brown of the Union Army, the first white person to treat her as a fellow human being. Her Southern mistress begins to beat the child: "Every time she hit me she asked me what my name was. I said Jane Brown. She hit me again: what I said my name was. I said Jane Brown" (Gaines 9). William Wells Brown recounts a similar incident that involved a moment when his master told him that he would no longer be called "William," the name that his mother had given him. He was told that he would have to answer to the name "Sandford:"

This, at the time, I thought to be one of the most cruel acts that could be committed upon my rights; and I received several very severe whippings for telling people that my name was William, after orders were given to change it. Though young, I was old enough to place a high appreciation upon my name. It was decided, however, to call me "Sandford," and this name I was known by, not only upon my master's plantation, but up to the time that I made my escape. I was sold under the name of Sandford. But as soon as the subject came to my mind, I resolved on adopting my old name of William, and let Sandford go by the board, for I always hated it. Not because there was anything peculiar in the name; but because it had been forced upon me. It is sometimes common, at the south, for slaves to take the name of their masters. Some have a legitimate right to do so. But I always detested the idea of being called by the name of either of my masters. And as for my father, I would rather have adopted the name of "Friday," and been known as the servant of some Robinson Crusoe, than to have taken his name. (Brown, Narrative 96-97)

10 Jane Brown follows William Wells Brown, and when freedom comes, all the slaves follow her lead: "Now everybody started changing names like you change hats. Nobody was keeping the same name old Master had given them" (Gaines 18).

11 Another incident in the novel that has its match in the slave narratives is significant because it actually takes place after the moment of liberation. The date is 1865 , and the slaves on the Louisiana Plantation have heard their Proclamation of Emancipation, and they know that they are free. The plantation slaves celebrate the Emancipation Proclamation that has been read to them by their master, who is their master no more. He has nothing to say to them; they have to think what it means, what to do, what to be. The first thought is that they should go North, and without geography or 
cartography, free though they are, they have to resort to traveling by the sun and stars. Jane gets this advice from Uncle Isom: "'Sun or your right in the morning, your left in the evening. North Star point the way at night. If you stay in the swamps, the moss is on the north side of the tree root"' (Gaines 14). William Wells Brown, the fugitive slave, reports exactly the same mode of direction finding:

We remained in the woods during the day, and as soon as darkness overshadowed the earth, we started again on our gloomy way, having no guide but the NORTH STAR. We continued to travel by night, and secrete ourselves in the woods by day; and every night, before emerging from our hiding-place, we would anxiously look for our friend and leader-the NORTH STAR. (Brown, 67-68)

The North Star was, of course, the name that Frederick Douglass gave to the paper that he and Martin Robinson Delany established in Rochester in 1847 to "abolish slavery in all its forms and aspects, promote the moral and intellectual improvement of the COLORED PEOPLE, and hasten the day of FREEDOM to the Three Millions of our enslaved fellow countrymen" (Douglass, North Star, 3 December 1847: 1).

The point is not that Gaines is copying Douglas and Brown; and Gaines is not rewriting The Narrative of William Wells Brown. What Gaines is doing is drawing on the great corpus of slave narratives that has come down to modern times. Marion Wilson Starling, in The Slave Narrative, reckons their number to be 6000 (Starling 337). From this vast trove Gaines is constructing his novel to celebrate that tradition and commemorate that tradition but especially to revisit that tradition. He does so to ask: what change? What change between 1861 and of 1961? The peculiar geography of African America means that the North is their West since to gain the promise of the American dream they had to run North. In slavery times, Americans talked of the Border States, Delaware, Maryland, Virginia, Kentucky and Missouri. These were the Northern-most slave states and they bordered on the Free States of New Jersey, Pennsylvania, Ohio and Indiana. However, William Wells Brown denied that there was any meaning in the term "Free States." He found in the North the cruel world of segregation, something that the slaves knew nothing about. The hostility of Northern whites came as a shock to slaves arriving to find people who wanted no physical contact with them at all, did not want to be in the same room, car, space as them, were actually more distant than the Southern whites who lived surrounded by blacks. William Wells Brown hated what he called the "nigger-hating" city of New York. It is well to remember that the free North invented Jim Crow and segregation. There was no need for that in the slave South. That's why the white lady tells Jane "There ain't no Ohio" (Gaines 30). Jane is going to experience the deathless, endless disappointment of America. And yet she is right to be running North and not to be going South like the dependent negroes freely returning to their plantation and now freely serving their white mistress. The child is right and heroic and should have history on her side. In fact, Jane does not and she begins to discover that there is no place to hide in the United States. In African America, all directions lead South: "But after what Bone had told us," says Miss Jane Pittman, "I had no more faith in heading North than I had staying South [...] It was slavery again, all right" (Gaines 72). Miss Jane Pittman's interviewer, the man taping the tapes, is a historian, and the lesson of Miss Jane's life story is to be a history lesson which teaches the great repeating cycle of the tragedy of black race.

14 Gaines's world consists of heroic silent but enduring women and heroic outspoken but short-lived men. The rest of mankind, black mankind at least, are watchers and 
followers. Jane Pittman says that these people were always looking for a leader, someone to save them in the hard times of Slavery, Reconstruction, the Depression. They look at each new born boy child, and they ask: "You the One?"--the One who will "carry part of our cross" (Gaines 211). The prototype of this Messianic figure would appear to be Frederick Douglass, a looming figure in the novel though he was in fact as enduring as any long-lived woman. He did not last one hundred years, but he did last a respectable seventy-seven, and he passed through every stage of African American life from a cruelly isolated slave childhood to an internationally respected old age. He is a point of reference in The Autobiography of Miss Jane Pittman, but he is not a figure who can enter the confined range of characters that Gaines admits to the novel. Jane Pittman quotes him at one point, just after her decision to stay South-"Mr Frederick Douglass said give the South a chance" (Gaines 74)-, but the strong, active and successful black male becomes symptomatically reduced to the tragic figure of the first of Miss Jane's symbolical sons, the boy called Ned whom she saves from the massacre of the patrollers in the opening pages (22).

Though married, Jane Pittman is both childless and she retains the maiden title 'Miss' to the end of her life. She is barren, and, for that reason, is childless, but her condition permits her to become the symbolic mother of her people; she is further the mother of not one but two messiah figures, Ned and, after the death of Ned, Jimmy. Gaines portentously constructs about his heroine a Holy Family, with Joe Pittman the horse breaker playing the role of Joseph the carpenter. She then plays a role of a Virgin Mother whose people are in need of a succession of Redeemers. As the first of her redeeming sons leaves home to begin his sacred (but hopeless) work, he graduates through a succession of names that spell out his developing role, in a fashion which echoes a major trope of the slave narrative: the hero's adoption of a full name, a name that will serve him in the world, a name that will identify him as a full citizen. This is the pattern that we have already seen Ticey the slave girl work through. In the section called "Ned Leaves Home," Ned becomes Ned Brown, Ned Douglass, Ned Stephen Douglass, and finally Edward Stephen Douglass in quick succession (Gaines 75-79), and the final form of his name makes him not only the symbolic son of Miss Jane Pittman, mother of the race, but the symbolic son of Frederick Douglass, too, father of the race.

Ned returns to the story when history has reached the end of the nineteenth century -"he came from that war in Cuba. That war ended in 1898. He came here that next summer" (Gaines 103)-and he returns as "Professor Douglass," and the theme of his lecture is "Was they teaching Mr. Booker T. Washington or was they teaching Mr. Frederick Douglass?" (Gaines 105). Frederick Douglass has now been dead four years, and his symbolic son is about his "father's business"-bearing the true message to the people. Behind the struggle of the true and false message, the true and false prophet, stands the greater issue of the duty of the Black Public Intellectual. What Wilson Jeremiah Moses says of Frederick Douglass was in fact true of all African American intellectuals:

He attempted to assume the position of public intellectual, but was never able to escape from the box of racial ambassadorship. Douglass believed that racialism was a reactionary doctrine, but he always remained "a race leader" and was never able to become a true "public intellectual," because the society was not color blind. (Moses 39) From the date of Benjamin Banneker's letter of August 19th, 1791 to President Thomas Jefferson to the recent battles of Cornell West and Henry Louis Gates with President 
Lawrence H. Summers, the role of what Michael Dyson calls "Black Public Intellectuals" (47) has always been strung between a duty to a discipline and a duty to a race. In January 2002, The Chronicle of Higher Education asked its readers to consider "what a president can ask, and whom scholars should serve" when Black Intellectuals-"blackstudies stars"-are caught between folk and faculty. Gaines's treatment of this dilemma does not raise any of its complexities because of his choice of the quasi-religious role that he gives his Saviors of the Race. Edward Stephen Douglass is Professor-PreacherPolitician, but he is also a self-appointed martyr. Between the setting of the final scenes of the novel and its publishing, that is in the decade of the 1960s, the stories of Martin Luther King and Malcolm X confirmed Gaines's fatalistic view of African American history. And in fact, of all the voices that might have been put into the mouth of Ned now become Professor Douglass, it is that of Malcolm X that sounds through his lecture-sermon-speeches:

"The white man came with rum and beads. And why? Because we was already waiting for him when he came there in ships. Our own black people put us up [113-114] in pens, like hogs, waiting to sell us into slavery" [...] "Be Americans," he told the children. "But first be men. Look inside yourself. Say, "What am I? What else beside this black skin that the white man call nigger?' Do you know what a nigger is?" he asked us. "First a nigger feels below anybody else on earth [...] But there is a big difference between a nigger and a black American. A black American cares and will always struggle." (Gaines 115)

The brutal use of the word "nigger" catches exactly the tone of Malcolm X's rhetoric; "nigger" was not a word used by Martin Luther King. For this outspokenness, Ned pays the great price and plays the great role. Miss Jane Pittman says of him:

He died at the end of the century. He shed his precious blood for them. I remember my old mistress, when she saw the young Secesh soldiers, saying "The precious blood of the South, the precious blood of the South." Well, there on that river bank is the precious dust of the South. (Gaines 119)

The death of Ned shot by the archetypal, unchanging and unchangeable racist Albert Cluveau leads the novel and the life of Miss Jane Pittman into its next historical cycle as she and the people begin to look again for the "One" who will lead the people. The people of the Quarters choose Shirley Aaron's child, Jimmy. He is to be a ProfessorPreacher-Politician, a Black Public Intellectual, of the stature of Ned, but Gaines places him first in a context of African American achievement that is both surprising and revelatory for Jimmy from Louisiana is compared with Joe from Alabama. "Joe had just tanned S'mellin'," says Miss Jane Pittman. (Gaines 212.) Joe is Joe Louis who knocked Max Schmeling out in the first round of the World-Title Fight in 1938. This huge sporting victory, like that of the track runner Jessie Owens in the Berlin Olympics of 1936, exposes at once the significance and the restriction of black achievement that is appropriated by the spectators as if it were their own. This confinement of the individual goes unchallenged by Gaines and he is as drawn into the delusions of the search for the One as much as any person living in the Quarters. At this point, his novel has entered the world of his own boyhood, and the joy of the little boy, working the sugar fields for fifty cents a day in the visions of the great African American heroes is untempered by reflections of the adult writer of the later 1960s. Jimmy can read and write as well as the teachers, and he listens to the old people talking about slavery, the high water, Huey Long and all the stories that have been told in this story (Gaines 219). At the same time a growing theme of religious commitment 
begins to spread though the fabric of the telling. The young Miss Jane Brown of the 1870s was at best an agnostic, and Miss Jane Pittman saw no need for a church marriage to Mr Joe Pittman in the 1890s-“We didn't get married. I didn't believe in the church then, and Joe never did. We just agreed to live together, like people did in slavery time. Slave didn't get married in churches, they jumped over the broom handle" (Gaines 81). But by the 1930s, she has got religion and when Jimmy grows up she waits for Jimmy to get it too. It will be one of the signs that he is the One. "He got religion the first week of August-that was back in 1951." He sadly says to the ancient woman: "I got religion, Miss Jane"' (Gaines 225).

But he has got religion in his own way, and it will lead to his martyrdom as lecturing led to Ned's: "It was “Termination Sunday. 'Termination Sunday is when you tell the church you still carrying the cross" (Gaines 235). Jimmy stands up last and asks the people to join him in protesting the way they are made to lead their lives. Elder Banks says: "'All we want to do is live our life quietly as we can and die peacefully as the Lord will allow," (Gaines 239). Almost alone among the quiet, backwater congregation, Miss Jane understands what Jimmy is saying: "I told him I could understand what he was trying to do because my boy had tried to do the same thing long long before he was born" (Gaines 241). The ambiguity of Gaines's racial thinking becomes very clear in the final iteration of the cycle that sees the One appear, grow up, become a leader of his people and then die in their cause with but a few knowing who he is or what he has done. The strength of the novel's central metaphor that the life of one woman is the life of her people becomes most evident at the moment when it might be said to be most invidious. Miss Jane Pittman is one who escaped slavery; she remains in the second half of the twentieth century a living relict of the system. She, like William Wells Brown, Frederick Douglass, and the great heroes and heroines of the slave narrative tradition, has lived life on the slave plantation, and she has escaped it. But it is not quite so clear that she has escaped in the complete fashion that Brown and Douglass so triumphantly escaped their plantations in Missouri and Maryland. One hundred years on, Miss Jane Pittman says: "I have a scar on my back I got when I was a slave. I'll carry to my grave. You got people out there with this scar on their brains, and they will carry that scar to their grave"' (Gaines 242). Arguably she has a scar on her brain too and so does Ernest J. Gaines. Gaines has his heroine make a powerful and undeniable statement. She says: "The likes of Albert Cluveau has not vanished from this earth" (Gaines 254), but in saying that she is not only speaking about the degeneracy of American racism and the evolving social structures that first embedded that racism and then sustained it. She is also empowering that racism. That she does it is true to the narrow vision and narrow character of the woman whom Gaines chooses to make the heroine of his novel. But Gaines's novel also empowers the Albert Cluveaus of this world, and what is forgivable in a character is less forgivable in a novelist. 


\section{BIBLIOGRAPHIE}

BANNEKER, Benjamin, Letter to Thomas Jefferson. Aug. 19th, 1791. University of Virginia Library. http://www.jmu.edu/madison/banneker/bannekerletter.htm. Sept. 13, 2002.

BELLOW, Saul, Herzog. New York: Viking, [1961] 1964.

BROWN, William Wells, The Narrative of William Wells Brown. 1847. Boston: The Anti-Slavery Office, 1849.

CABLE, George Washington, “The Freedman's Case in Equity.” The Century Magazine (January 1885): http://etext.lib.virginia.edu/railton/huckfinn/hfequity.html

CLARK, Keith, Black Manhood in James Baldwin, Ernest J. Gaines, and August Wilson. Urbana: University of Illinois Press, 2002.

CRAFTS, Hannah, The Bondwoman's Narrative. 1857? Ed. Henry Louis Gates, Jr. New York: Warner Books, 2002.

DELANY, Martin R, Blake; or the Huts of America. Introduction by Floyd J. Miller. Boston: Beacon Press, 1970.

DOUGLASS, Frederick, The North Star (3 December 1847).

DOYLE, Mary Ellen, Voices from the Quarters: The Fiction of Ernest J. Gaines. Baton Rouge: Louisiana State University Press, 2002.

DYSON, Michael Eric, Race Rules: Navigating the Color Line. New York: Addison: Wesley, 1996.

GAINES, Ernest J., The Autobiography of Miss Jane Pittman. New York: Bantam, [1971] 1972.

GAYLE, Addison, Jr., Introduction. The Black Aesthetic. Ed. Addison Gayle, Jr. Garden City: Doubleday, 1971.

JOHNSON, Thomas, The Oxford Companion to American History. New York: Oxford UP, 1966.

MOSES, Wilson Jeremiah, Afrotopia: the Roots of African American Popular History. Cambridge: Cambridge UP, 1998.

STARLING, Marion Wilson, The Slave Narrative: Its Place in American History. Washington: Howard University Press, 1988.

WEBB, Frank J, The Garies and Their Friends. London: Routledge, 1857.

WILSON, Harriet E, Our Nig or, Sketches from the Life of a Free Black, In a Two-Story White House, North. Showing that Slavery's Shadows Fall Even There. 1859. Ed. R. J. Ellis. Nottingham: Trent, 1998.

WILSON, Robin and Scott SMALLWOOD, "Battle of Wills at Harvard." Chronicle of Higher Education (January 18, 2002): http://chronicle.com/free/v48/i19/19a00801.htm

\section{RÉSUMÉS}

This paper explores the ways in which Ernest J. Gaines uses fiction in The Autobiography of Miss Jane Pittman to write a history of the African American from 1861 to 1961. The "Introduction" sets the novel going, but its direction has already been given in the unusual dedication to his grandmother, stepfather and aunt "who did not walk a day in her life but who taught me the 
importance of standing" (Gaines iv). The significance for Gaines is that what happened a hundred years ago is part of his present-day lived life.

The nineteenth-century novel was possessed by history, and white nineteenth-century novelists found their great subject in the war of European nations that was fought between 1799 and 1815 . But that was not an American war nor was it an African American war. For Gaines, the war that makes the great turning point of a nation and a people is the American Civil War, fought from 1861 to 1865 . It resulted in a moment of history after which life would not be the same. However, one of the main points that Gaines makes about that great turning point in history is that everything changed and nothing changed. And his main fictional device to establish that truth is to tell the history of the hundred years since Emancipation as the story of one woman. Her autobiography becomes an ethno-biography.

The continuity forwards from 1861 is given through the life of one woman, but Gaines's uses another device to provide a continuity backwards from 1861. The young man who wants to get Miss Jane Pittman's story upsets her with his persistence: “What you want know about Miss Jane for?' Mary said. 'I teach history,' I said. 'I'm sure her life's story can help me explain things to my students.' 'What's wrong with them books you already got?' Mary said. 'Miss Jane is not in them,' I said" (Gaines v). Ernest J. Gaines wrote at a time when historians finally began to recognize that they could get no true history of the South if they allowed that history to be written by plantation owners. In the sixties and the seventies, the pre-Civil War slave narratives, so long dismissed as lies and fictions by white Southern historians, began to be read again, and began to tell African Americans another history. Gaines used the then un-mined resources of the slave narratives to provide structure, themes, characters and incidents for his novel. A comparison of The Autobiography of Miss Jane Pittman with the Narrative of William W. Brown, A Fugitive Slave Written by Himself, published in 1847, will show how close these links are. But William Wells Brown's Narrative is only one of at least sixty pre-Civil War slave narratives, and, though it is an exceptionally good one, there is another reason for singling out its author.

William Wells Brown was the first African American to publish a novel: Clotel; or the president's daughter. That appeared in 1853, and up to that date Brown, like Equiano, Douglass, Bibb, Henson, Pennington, and the many others who wrote an account of their life as a slave and their escape from the South had had to contend with the Southern cry that everything the fugitive slaves was saying was lies, and that they did not write their own stories but got white Northerners to write them for them. It was the publication of Harriet Beecher Stowe's Uncle Tom's Cabin in 1852 which showed William Wells Brown (and Frederick Douglass) that fiction might serve the abolitionist cause as much as a true narrative faithfully attested.

In 1853, with the publication of his novel Clotel, William Wells Brown took African American narrative in a direction that was new and dangerous. In 1971, with the publication of his novel Miss Jane Pittman, Ernest J. Gaines returned African American fiction to its roots, and he did so with a didactic purpose remarkably like that of William Wells Brown. For all that he had been a slave there, Brown seems to have loved the South more than he loved the North. He called his last work My Southern Home, and he was never at home in the North. To his dismay and disgust when he reached Ohio and freedom in 1834, he found a physical hatred of blacks that he had not experienced in the slave states. He had run from Slavery to Segregation. And that is the story that Miss Jane Pittman has to tell of African Americans running from 1861 to 1961. 
INDEX

Mots-clés : historiographie, autobiographie, géographie, histoire, Intellectuels noirs, nom, récit d'esclave, roman du 19ème siècle

Keywords : historiography, autobiography, geography, history, archétype, Brown William W., Douglass Frederick, emancipation, fiction, Gaines Ernest J., ségrégation, stéréotype, archetype, Black Intellectuals, name, nineteenth-century novel, segregation, slave narrative, stereotype

\section{AUTEUR}

\section{CHRISTOPHER MULVEY}

Christopher Mulvey is Professor at the University of Winchester (Great-Britain). 